\title{
Management Theory and Studies for Rural Business and Infrastructure Development
}

ISSN 2345-0355. 2019. Vol. 41. No. 1: 127-134

Article DOI: https://doi.org/10.15544/mts.2019.12.

\section{CREATIVITY AS A NEW PRODUCTION FACTOR OF THE WORLD ECONOMY}

\author{
Oleg Shvidanenko ${ }^{1}$, Edgardo Sica ${ }^{2}$, ${ }^{*}$ Tatiana Busarieva ${ }^{3}$ \\ Prof. Dr. Kyiv National Economy University Named After Vadym Hetman. Address: 54/1 Prospect \\ Peremogy 03057 Kyiv, Ukraine.Tel.+380675656524.E-mail o.shvidanenko@gmail.com \\ Assistant Prof. Dr. Department of Economics, University of Foggia. Address: Largo Papa Giovanni \\ Paolo II, 71121 Foggia, Italy.Tel.: +390881781711.E-mail: edgardo.sica@unifg.it \\ Assoc. Prof. Dr. Kyiv National Economy University Named After Vadym Hetman. Address: 54/1 \\ Prospect Peremogy03057 Kyiv, Ukraine.Tel.+38093 4018596.E-mail: sutner@ukr.net
}

Received 1402 2019; Accepted 07032019

The transition to the postindustrial society, which marks the beginning of the humanity's entry to the information age, which is not based on the mechanical engineering, but on intellectual technology, makes creativity as the main resource of all the scientific and technological processes. Relevance of the article is due to the dynamic changes of the epoch of world socio-cultural development to the new epoch of creativity, where human resource goes out on the qualitatively new level. The aim of the article is to analyze the processes of transformation of production factors and the substantiation of creativity as an imperative for the development of the world economy. The methodological basis of the article is the methods and forms of scientific knowledge adopted in domestic science, such as system approaches, comparative and synthesis methods, methods of abstract logical evaluation, methods of detailing, groupings and generalizations, experts' evaluations. Analysis of the transformation of the factors of production was revealed; creativity was allocated as the new factor of the production and the necessity of its further development was proved. Results: the changes of the productive factors were revealed, the importance of the development of creativity as the new factor of production was proved, the modern theories of creativity were presented.

Key words: creativity, factor of production, creative economy.

JEL Codes: D83, J24, O30.

\section{Introduction}

In the modern conditions global economy has experienced rapid transformational development from a knowledge economy, through an innovative, to the economy of creativity. At the same time, if such terms as the knowledge economy, innovation, information and intellectual economy are often used as synonyms, the concept of a creative economy is filled with new content and acquires several qualitatively new signs

Copyright (C) 2019 The Authors. Published by Vytautas Magnus University, Lithuanian Institute of Agrarian Economics. This is an open access article distributed under the terms of the Creative Commons Attribution NonCommercial 4.0 (CC BY-NC 4.0) license, which permits unrestricted use, distribution, and reproduction in any medium, provided the original author and source are credited. The material cannot be used for commercial purposes.

* Corresponding author 
and properties. At the same time, it can be argued that the creative economy does not deny the previous forms of development, but rather uses them as the basis of its further transformation.

It is important to emphasize that in the modern economy, creativity is considered not only as a key factor in the country's economic competitiveness, but also as a vector of development, which is bound to both the formation of the individual and society.

In other turn, if education and the intellectual product are the key factors of the knowledge economy, and the innovative economy sharpens attention on the ways of using this knowledge, the task of the creative economy is to provide conditions for generating ideas, on means of transforming the proposed ideas into a qualitatively new product. Thus, the formation of the paradigm of creative economy, where creativity acts as a new factor of production along with the classical factors of production, is spurious.

\section{Analysis of the transformation of the factors of production}

In the conditions of accelerated development and transition to postindustrial society, the importance of representing a system of factors of production increases, that acts as variables of the production functions of the XXI century. In various economic theories, the question arises of the independence of factors in one of their systems and the unity of the criteria for their separation. The theoretical methodological substantiation of the system of factors of production has been carried out for more than 100 years within the framework of all classical and non - classical theories historically conquered in economies.

The classical economic theory has formed an idea of the composition of the factors of production - labor, land, capital, singled out according to a single objective criterion. The independence of classical factors of production was questioned by K. Marx, who combined the means and objects of labor (capital and land) into a material factor of production. And Marshall (1890) distinguishes "organization" from the factor "capital" into a special factor of "production". Later, Schumpeter (1932) rejected the "capital" factor. At the same time, investigating the essence of the factor "labor", J. Schumpeter divides it into two parts: "executive labor" and "management labor" or "entrepreneurial function". The entrepreneurial function - the function of "implementing new combinations" is approved by J. Schumpeter as the third factor of production. The introduction of an "entrepreneurial function" as a separate factor, along with "land" and "labor," violates the unity of the criterion by which the factors of production should be allocated in one of their systems, which in turn leads in our opinion to critical perception and alienation. So, the factor "entrepreneurial function" is distinguished by the functional criterion.

From the middle of the 20th century, as researchers understood the prospects of the transition to a post-industrial society, the system of factors of production was 


\section{Management Theory and Studies for Rural Business and Infrastructure Development}

ISSN 2345-0355. 2019. Vol. 41. No. 1: 130-136

Article DOI: https://doi.org/10.15544/mts.2019.12

supplemented by such factors as "human capital" and "scientific and technical progress", "information", "knowledge", etc. (Schulz, Becker, Solow, Mansfield, Bell, and others.). So, the American sociologist Bell (1892) argues that "both labor and capital were central variables in an industrial society, so information and knowledge become the decisive variables of a post-industrial society". Solow (1988) introduces "scientific and technical progress" in the composition of the variables of the production function. In domestic science, the number of researchers considering information as a factor of production is growing (Klejner, Toffler, Fransmen, Cohen, Soto etc.).

Separately, it should be noted innovative theories of factors of production, the analysis of which led to the development of categories that reveal the factor "capital" "intellectual capital", "intellectual potential", "creative capital" (Thorow, Bell, Houghton, Sheehan). These factors imply costs in human resources, investments in R \& D, trademark, patents, know-how, management qualifications, corporate culture, corporate architecture, corporate ethics, as well as the development of personal qualities of a person that allow him to carry out higher activities, his readiness generate ideas.

Thus, we can highlight the fact that in the works of neoclassical economists there is a tendency to expand the system of factors of production by introducing, along with the factors "labor", "land", "capital", factors "entrepreneurial ability", "information", "knowledge", "organization", "technology", "scientific and technical progress", "infrastructure", etc. Moreover, the input factors are distinguished both by objective (labor, land, capital) and by functional (entrepreneurial ability, organization, technology, scientific technical progress) criterations.

However, at the beginning of the XXI century, the formation of creativity as a factor of production went through several scientific directions, in which lies the understanding of creativity as a phenomenon and as a process. The term "creativity" was widespread in the 1950s in psychology: the American psychologist P. Torrens (1963) defined creativity as a sensitivity to problems, deficits and gaps of knowledge; combining diverse information, disharmonious elements; identify related problems, search for solutions to them.

By the beginning of the 60-th of the XX century a large-scale experience of testing intelligence was already accumulated, which led to the conclusion that people with not very high IQs are capable of outstanding achievements, and many others whose IQ is much higher often lag behind them. It was suggested that some other qualities of the mind, which are not covered by traditional testing, play a crucial role here.

In 1967 J. Guilford combined these factors in the general concept of "divergent thinking," which reflects the cognitive side of creativity. Compared with convergent thinking, focusing on the well-known, trivial solution of the problem, divergent thinking manifests itself when the problem has yet to be determined and when there is no preprescribed, established solution. Guilford (1967) focused on the analysis of the lane and song error, which only emphasized the creative composition of creativity. 
One of the authors Lineini (1971) mistake is a formal character, which is characterized by the logic of the reflex of the intuitivists. Nonlinear missionaries, Novapaks (1977), characterized by intuition, paradoxical and chaotic. In connection with the reference, creativity is not a product of diversity that is not related to logic, but it is vitally related to the characteristics of the subject, subject, process, the requirement of creativity, to add creativity to an independent confusion.

However, Torrance (1974) proved that creativity is nothing more than an emotional component of intellectual activity, the search for new knowledge beyond critical knowledge, the ability to go beyond logical generalization, and the ability to implement the work out of a critical generalization.

Since the late 1990s, creativity has become a necessary component of any activity, as the activity itself is turning into an increasingly complex social and technological level. The ratio of creative and reproductive components of activity shifts towards the first. Now "geniuses" are already needed in proportion, to say the least, one to one thousand, and one to ten, in some types of activities and to one another, up to two. Moreover, it turned out that creativity in a person can be developed, it can be taught.

Thus, the strategies of creative (or creative) industries are based on the social and technological phenomenon of increasing the number of creative people necessary for a successful and effective activity in any sphere. All that allows it to respond more quickly to market needs, easier to master new realities, adapt to them and see fundamentally new products.

That's why from our point of view, in the conditions of the formation of the paradigm of creative economics, the development of creativity should be considered in the context of the formation of "intellectual entrepreneurship". Intellectual entrepreneurship, in our opinion, should be understood as a special type of activity of intellectual entrepreneurs to create favorable conditions for satisfying complex human needs, aimed at its development and shaping the future, based on knowledge, are constantly being updated.

Analyzing modern theories of creativity, it is necessary to score, as Landry (2004) and Bianchini (2007) argued that "the industries of the twenty-first century will increasingly depend on the generation of knowledge created through creativity and innovation". According to Hawkins (2008) in the modern creative economy, creative ideas, patents, copyrights, trademarks and original designs have a decisive influence on the growth and development of the most successful companies in the world. Today, modern researchers conclude that in the new creative economy, it is creativity, innovation, and the generation of new ideas that represent an important corporate capital, the main resource and factor of production.

At the same time it is necessary to mention that famous American scientist Florida (2010) put forward the idea that the post-industrial economy forms a new social group, the creative community, so called the "creative class", which is becoming today an 


\section{Management Theory and Studies for Rural Business and Infrastructure Development}

ISSN 2345-0355. 2019. Vol. 41. No. 1: 130-136

Article DOI: https://doi.org/10.15544/mts.2019.12

increasingly influential force and acts as the core of modern society, as the main resource and factor of production. The scientist offers his own classification of occupations according to their participation in the labor process and the degree of employee creativity in the structure of the enterprise. The author considers management professions, professions in the field of business, finance, law, and professions in the field of health care (doctors and technical specialists) to be creative professionals. The main distinctive factor of the creative class from all the others, according to the classification of R. Florida, is that for which workers receive their money.

As for the development of creativity in TNCs, it is necessary to mention, that for them the knowledge, experience and creativity have become the main factor in the effectiveness of an organization, without which scientific progress is an unattainable task, regardless of the amount of funds invested in production equipment and technology. According to experts, up to 40\% of GDP in developed countries during 2017 is created by creative workers. The use of abilities embodied in people allows organizations to activate innovations, improve the quality and competitiveness of products and services.

As a result of the transformation of production factors, there is a need for new methods to improve the efficiency of innovation groups in modern organizations. Today, individual creativity has given way to the collective forms of generating and implementing new ideas. If before companies focused on financial and moral incentives for disparate inventors, today innovation is built on the basis of bringing innovators into communities, creative groups and innovative platforms, and it is stimulated primarily through the creation of a creative environment.

One of the most common forms of combining innovators within the companies is to create professional communities of innovators. A number of companies have organized prestigious societies of innovators: for example, "Victor Mills Society" in Procter \& Gamble, "IBM Fellows program" in IBM, "Carlton Society" in 3M, "PPG Collegium" in PPG Industries. Membership in the community enhances the reputation of a specialist in the eyes of colleagues and management, and provides access to information resources, special events for the exchange of experience and training programs. In addition, the reward of innovative teams is popularized; innovations are increasingly awarded not individual, but collective awards. A cross-functional project team is organized at NUMMI, a subsidiary of Toyota, to design a model production of new cars, the members of which return to their workshops after completion of the development. In companies such as Motorola, Mayo Clinic, Fisher-Price and Procter \& Gamble, cross-functional teams working separately from the main office and called "innovative laboratories" are formed to develop new products. 
Procter \& Gamble regularly hosts meetings on innovations ("Innovation Reviews"), during which experience is shared and new solutions are sought.

\section{Conclusions}

1. It can be stated that the emergence of creativity as a defining element of economic development lies in the center of a continuous process of change. Creativity has received appreciation due to the increasing recognition of the fact that it is the source of new technologies, new industries, new material goods and other economic advantages.

2. In the period of the formation of the creative economy, it is logical to form a new paradigm of the development of the society: creativity becomes the most significant factor influencing the production of products in economically developed countries, since it can realize its intentions in the process of labor and the creation of capital. And although creativity is intangible, thanks to new original ideas, without special additional labor and capital costs, it allows for an increase in the level of production. In addition, this human ability is unlimited resources for the formation of competitive advantages of TNC.

3. The modern economical world is rapidly changing the functions of production and management. In this tandem, creativity is considered as a key factor and the highest goal of development and organization of society. Competitive TNC that determine creativity as an important economic factor of their further development, are interested in the formation of a creative organizational culture on the base of the accumulation of knowledge of employees and their growth through the "labyrinth of creativity.

\section{References}

Hvizdova, E., Mokrisova, V., Polacko, J. (2016). Changes in research and development after crisis in selected countries // Economic Annals-XXI. Vol. 160(7-8):3134 - https://doi.org/10.21003/ea.V160-06 [13.08.2018].

AbuMezied, A. (2016). What role will education play in the Fourth Industrial Revolution? - https://www.weforum.org/agenda/2016/01/what-role-will-education-play-in-the-fourth-industrialrevolution/ [21 07 2018].

Kubik, G.H. (2013). Limitless: becoming remarkable in the borderless economy // On the Horizon. Vol. 21(2): 114-126. -https://doi.org/10.1108/10748121311323012 [13 08 2018].

Cooke, Ph. (2017). Complex spaces: global innovation networks \& territorial innovation systems in information \& communication technologies // Journal of Open Innovation: Technology, Market, and Complexity. Vol. 3. No. 1: 1-23 - https://doi.org/10.1186/s40852-017-0060-5 [13.08.2018].

Jaehan, Ch. (2018). Knowledge transfer to foreign affiliates of multinationals through expatriation. // Journal of International Economics. Vol. 113: 106 -117 https://doi.org/10.1016/j.jinteco.2018.04.006 [13.08.2018].

Baculakova, K. Harakalova, L. (2017). Creative industries in the EU: factors influencing employment // Economic Annals-XXI. Vol. 164(3-4): 40-44. -https://doi.org/10.21003/ea.V164-09 [13.08.2018]. 


\title{
Management Theory and Studies for Rural Business and Infrastructure Development
}

ISSN 2345-0355. 2019. Vol. 41. No. 1: 130-136

Article DOI: https://doi.org/10.15544/mts.2019.12

Klinger B., Lederman D. (2006). Innovation and Export Portfolios Policy: Research Working
Paper; No. 3983. $\quad$ World $\quad$ Bank:
https://openknowledge.worldbank.org/handle/10986/8362 [19 07 2018]. Boutellier, R., Gassmann, O., von Zedtwitz, M. (2008). Managing Global Innovation. Uncovering the Secrets of Future Competitiveness. - Springer-Verlag Berlin Heidelberg. 626 p.

Blinder, A. (2008). Education for the Third Industrial Revolution //CEPS Working Paper. No. 163: 1-19 -https://www.princeton.edu/ceps/workingpapers/163blinder.pdf [21 07 2018].

Jensen, K. R. (2017). Leading Global Innovation: Facilitating Multicultural Collaboration and International Market Success. - Springer-Verlag Berlin Heidelberg. 182 p.

Card, D. (2005). Is the New Immigration Really So Bad? // Economic Journal. Vol. 115. No. 507: 300-323. - https://doi.org/10.3386/w11547 [13.08.2018].

Choudaha, R., Wit, H. (2014). Challenges and Opportunities for Global Student Mobility in the Future: a comparative and critical analysis, In B. Streitwieser (Ed.) // Internationalisation of Higher Education and Global Mobility. - Oxford: Symposium Books: 19-33doi: https://doi.org/10.15730/books.87 [13.08.2018].

Paleari, S., Donina, D., Meoli, M. (2015). The Role of the University in Twenty-first Century European Society // Journal of Technology Transfer. Vol. 40. Issue3: 369-379. - https://doi.org/10.1007/s10961-014-9348-9 [13.08.2018].

Open Innovation: Technology, Market, and Complexity. Vol. 3. No. 1: 1-23 - https://doi.org/10.1186/s40852-017-0060-5 [13.08.2018].

Global creativity index. (2017). - https://www.globalinnovationindex.org/gii-2017-report\# [12 $112018]$.

Florida, D. (2010). Impact of selected structural factors on employee involvement //Education of Economists and Managers.Vol.2. No.12: 65 -81

\section{KŪRYBIŠKUMAS KAIP NAUJAS PASAULIO EKONOMIKOS GAMYBOS VEIKSNYS}

\author{
Oleg Shvidanenko ${ }^{1}$, Edgardo Sica², *Tatiana Busarieva ${ }^{3}$ \\ ${ }^{1,3}$ Kijevo nacionalinis ekonomikos universitetas, Ukraina, ${ }^{2}$ Foggia universitetas, Italija
}

Gauta 201902 14; priimta 20190307

\section{Santrauka}

Šio straipsnio aktualumą diktuoja pasaulio sociokultūrinio vystymosi epochos dinaminiai pokyčiai, pereinant prie naujos kūrybiškumo epochos, kurioje žmogiškasis išteklius atsiduria kokybiškai naujame lygmenyje. Šio straipsnio tikslas - išanalizuoti gamybos veiksnių transformacijos procesus ir pagrịsti kūrybiškumą kaip būtiną sąlygą vystant pasaulio ekonomiką. Straipsnio metodologinị pagrindą sudaro namų ekonomikos moksle priimti metodai ir mokslo žinių formos, tokie kaip sisteminiai metodai, lyginamasis ir sintezès metodas, abstraktaus loginio vertinimo metodai, detalizavimo, grupavimo ir apibendrinimo metodai, ekspertų vertinimai. Rezultatai: atlikus analizę, atskleista gamybos veiksnių transformacija; kūrybiškumas priskirtas prie gamybos veiksnių kaip naujasis veiksnys, ir pateiktas jo tolesnès plètros būtinybès pagrindimas.

Raktiniai žodžiai: kürybiškumas, gamybos veiksnys, kūrybinè ekonomika.

JEL kodai: D83, J24, O30.

\footnotetext{
* Autorius pasiteirauti
} 